1977-12-01

\title{
Leaf litter processing in aquatic systems two variable model
}

Boyd Jay Hanson

Brigham Young University - Provo

\section{BYU ScholarsArchive Citation}

Hanson, Boyd Jay, "Leaf litter processing in aquatic systems two variable model" (1977). Theses and Dissertations. 7945.

https://scholarsarchive.byu.edu/etd/7945

This Thesis is brought to you for free and open access by BYU ScholarsArchive. It has been accepted for inclusion in Theses and Dissertations by an authorized administrator of BYU ScholarsArchive. For more information, please contact ellen_amatangelo@byu.edu. 


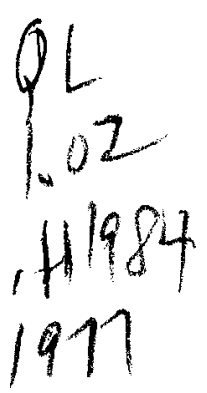

LFAF LITTER PROCESSING IN AQUATIC SYST'EMS:

A TWO VARIABLE MODEI

A Manuscript of a Journal Article

Presented to the

Department of Zoology

Brigham Young University

In Partial Fulfillment

of the Requirements for the Degree

Master of Science

by

Boyd Jay Hanson

December 1977 
This manuscript by Boyd Jay Hanson is accepted in its present form by the Department of Zoology of Brigham Young University as satisfying the thesis requirement for the degree of Master of Science.

Typed by Michele Hutchings 


\section{ACKNOWLEDGEMENTS}

I extend appreciation to Dr. James R. Barmes for his friendship and encouragement during the past five years. I also thank him and Dr. Melvin W. Carter for their extensive assistance during the preparation of this manuscript. I have appreciated the association and assistance of Dr. Lee F. Braithwaite and Dr. Sam Rushforth. Dr. Kenneth W. Cummins provided much of the data presented in the manuscript, and contributed to the preparation of the paper.

My parents and family have aided financially and have been sources of encouragement. Special thanks go to my wife for her continual support. 


\section{INTRODUC'PION}

Aquatic leaf litter processing is an important part of overall stream metabolism, especially in headwaters streams where allochthonus leaf material may constitute over $90 \%$ of the annual energy budget (Hall, 1972; Fisher and Likens, 1973). The processing of leaf litter, a component of the course particulate organic matter ( $\mathrm{lmm}$; CPOM), involves the loss of dissolved organic matter (DOM), conversion to fine particulate organic matter ( $4 \mathrm{Imm}$; FPOM), organism biomass, and $\mathrm{CO}_{2}$. Processing rate is dependent upon a number of factors: leaf species (Petersen and Cummins, 1974); size of the litter accumulation (Reice, 1975); preconditioning in the terrestrial environment (0lson, 1963); and the biological (Petersen and Cummins, 1974; Suberkropp and Klug, 1976), physical (Reice, 1975; Sedell et al., 1975), and chemical (Cummins et, al., 1972) characteristics of a given stream reach.

The determination of an accurate yet parsimonious model describing this process could be accomplished by two methods. After fitting a model using all parameters which may affect the process, those which are not significant are removed until a model with only necessary factors remains. In the other approach, parameters are added to a simple model until the fit is adequate; this is the method used in the present paper.

Petersen and Cummins (1974) proposed that stream leaf litter processing could be described using the negative exponential model employed by 0lson (1963) for terrestrial litter. Use of this model 
implies that a constant fractional amount of leaf material is processed per given time period and the proportional amount of leaf litter processed is a negative exponential function of the product of a rate coefficient and a measurement of the processing time. The processing rate coefficient is assumed to be constant throughout the entire processing period.

Graphically this model seems to fit experimental data, but its statistical significance has not been examined. The assumption of a constant processing rate seems plausible in certain situations but a change in biological, chemical, or physical parameters during processine may affect the actual rate. Fitting the negative exponential model would in this case determine an "average" rate coefficient for the processing period which may not be adequate during changing conditions. Adding the varying parameters to the model allows the examination of the effect of their changing levels on the rate coefficient. For instance, water temperature frequently changes during processing periods and in some cases markedly affects the rate coefficient.

Temperature has been cited as an important rate regulating factor, especially through its effect on microbes (Barlocher and Kendrick, 1974; Suberkropp et al., 1975; Suberkropp and Klug;, 1976). Macroinvertebrate shredders may play a more dominant role in processing when low temperatures reduce microbial growth rates. At higher temperatures microbes, particularly aquatic hyphomycete fungi, control processing rates (Barlocher and Kendrick, 1974). 
In the treatment described below, the adequacy of the negative exponential model in describing several data sets has been tested statistically. The significance of adding temperature to the model was also tested with the same data sets.

\section{IMETHODS}

\section{Statistical Procedures.}

The negative exponential model employed by Olson (1963), and Petersen and Cummins (1972) is a simple model with time as the single independent variable, and unprocessed litter as the single dependent variable. The model can be written in the following form:

$$
\begin{aligned}
\mathrm{W}_{\mathrm{D}}= & \mathrm{W}_{\mathrm{O}} \mathrm{e}^{-\mathrm{kD}} \text { where: } \\
\mathrm{W}_{\mathrm{D}}= & \text { Amount of leaf material remaining } \\
& \text { after } \mathrm{D} \text { days } \\
\mathrm{W}_{\mathrm{O}}= & \text { Initial amount of leaf material } \\
\mathrm{k}= & \text { Rate coefficient } \\
\mathrm{D}= & \text { Elapsed time (measured in days) }
\end{aligned}
$$

The non-linearity of the model precludes estimation of the parameters by standard least squares regression techniques, without a transformation of the data. A natural log transformation yields the form:

$$
\text { In } W_{D}=\ln W_{0}-k D \text {. }
$$

In this linear form the model can be fit using least squares regression, and the significance of the relationship between time 
and amount remaining can be determined by an F-test on the significance of the regression. However, a significant regression does not imply that the model is adequate. The change in the independent variable (days) may partially describe the change in the dependent variable (amount remaining), but this relationship could leave a significant portion of the change in the dependent variable unaccounted for.

When an experiment is conducted with replication at sampling points, the fit of a model can be tested using an F-test for lack of fit (see Neter and Wassermann, 1974). A non-significant test implies that the model adequately describes the data; while a significant test implies that the hypothesized model does not fit the data. Lack of fit may result from the omission of necessary terms from the regression model or the use of an inappropriate model.

All experiments examined in this paper were conducted with replication allowing a test for lack of fit at a significance level of .05; thus, there is a $5 \%$ chance of finding a significant lack of fit even if none exists.

The effect of temperature on processing, even though complex, might be satisfactorily estimated by some simple function of the rate coefficient. Though not as accurate, such a function could be more easily estimated and interpreted than a complex one. It has been suggested that over temperature ranges from $0-20^{\circ} \mathrm{C}$ that the weight loss (processing rate) is proportional to temperature 
(Suberkropp et al., 1975). This relationship indicates that the rate coefficient may be linear function of temperature rather than a constant as was previously assumed. The proportional amount of leaf material remaining after a given time would be an exponential function of the product of time and a rate coefficient dependent linearly upon temperature, instead of an exponential function of time and a constant rate coefficient as in the single variable model (Olson, 1963; Petersen and Curmins, 1974).

If the rate coefficient is assumed to be a linear function of temperature, the negative exponential model could be more appropriately written as:

$$
\begin{aligned}
& W_{D}=W_{0} e^{-k(T) D} \text { where: } \\
& T=\text { temperature (measured in }{ }^{\circ} C \text { ). }
\end{aligned}
$$

If $k(T)$ is then expanded as a linear function:

$$
\begin{aligned}
& k(T)=b_{0}+b_{1} T \text { where: } \\
& b_{0}=\text { intercept } \\
& b_{1}=\text { slope }
\end{aligned}
$$

the processing equation becomes:

$$
W_{D}=w_{0} e^{-\left(b_{0}+b_{1} T\right) D}
$$

This equation can be fit using multiple least squares regression after the data are logarithmically transformed. The transformation produces the following forms:

$$
\text { or } \begin{aligned}
& \ln w_{D}=\ln w_{0}-\left(b_{0}+b_{1} T\right) D \\
& \ln w_{D}=\ln w_{0}-b_{0} D-b_{1} T D .
\end{aligned}
$$


In the latter form the first independent variable is a measure of time (days), as used in the single variable model. The second variable is a measure of accumulated temperature over time. For the data considered in this paper, the summation of the average daily temperatures, or degree days, was used as the second variable (Andrewartha and Birch, 1954). Using Equation (7) $b_{0}$ and $b_{1}$ can be estimated by multiple least squares regression analysis (Neter and Wassermann, 1974).

The significance of adding temperature to the model can be determined using two criteria; lack of fit, and significance of the coefficient for degree days. In those cases in which there is a significant lack of fit using the model with days alone (Equation (1)), the data can be fit using two independent variables, days, and degree days. If the lack of fit is not significant using the second model, temperature has an important affect on processing rate.

When two or more parameters are fit in a regression equation, cach can be tested to determine if it is required in the model. In the model with days and degree days, each can be tested for its contribution. A significant test indicates that the parameter adds infcrmation to the description of the dependent variable (amount remaining) and should be kept in the model. If both are significant, then both are needed in the model; if neither is significant, either alone is adequate.

A biological interpretation of these tests can be made from Equation $(6)$. When $b_{o}$ (coefficient for days) is significant, it 
means that the linear function $k(T)$ does not have an intercept of zero; that is, the data do not indicate that processing ceases at zero degrees. Zero processing may be predicted either slightly above or below zero degrees. When $b_{1}$ (coefficient for degree days) is significant, the slope of the linear function is significantly different from zero. Thus, the rate change resulting from temperature change during the experiment was great enough to be significant; that is, temperature significantly affected the leaf litter processing rate. The rate change may be either negative or positive; processing rate being either accelerated or slowed by increasing temperature. The significance of the temperature effect upon processing rates in the experiments examined was tested using both criteria.

Biological Procedures and Site Description

The leaf pack method (Cummins, 1972, 1974, 1977; Petersen and Cummins, 1974) was used to simulate natural litter accumulations in streams and in the littoral zone of a lake. This procedure has been utilized in preference over various mesh bag enclosures to insure a natural oxygen regime and ready immigration and emigration of the biota-- conditions which do not exist in mesh bag samplers (Fark, 1974; M. J. Klug,KellogE Biological Station, unpublished data). Five or ten gram (dry wt.) packs of leaves were fastened together with "buttoneers" (Dennison Mfg. Co.), lashed loosely to bricks with monofilament nylon line and placed in the stream facing into the current to simulate the way leaf litter accumulates at the 
leading edge of obstructions. Five gram leaf packs, of similar construction to the stream packs, were tied with $20 \mathrm{~cm}$ of monofilament to an anchored wood support and then positioned directly on the lake substratum.

Initial weight was taken as pack weight after three days in the aquatic environment, following major leaching (Petersen and Cummins, 1974) and initial mechanical breakage due to handling and physical abrasion. At sampling times, packs were lifted from the stream in front of and into a 250 mn mesh net. Lake packs were recovered by SCUBA divers, and the packs were placed in cloth bags to prevent loss of associated macroinvertebrates.

In laboratory, leaves were carefully washed onto a $500 \mathrm{~mm}$ mesh screen and the fragments were retained with the leaves. Leaf pack weights were determined from oven dry weights $\left(50^{\circ} \mathrm{C}\right.$ at least $48 \mathrm{hrs}$ ). Field temperatures were measured with Bristol recording thermographs or Taylor maximum-minimum thermometers read at least weekly.

Three sets of leaf pack data (Table I) were analyzed using the statistical procedures previously described. The first experiment was conducted in Gull Lake, Michigan. Five gram white oak (Quercus alba) and pignut hickory (Carya glabra) leaf packs were placed at 2.5 and 6.0 meter depths, and oak packs were also placed at 12.0 meters in April, 1975. Replicate sets of three packs were removed approximately every 300 degree days through July, 1975. The processing of ten gram pignut hickory 
packs was examined at 6 sites on Augusta Creek, Michigan from October, 1974 through April, 1975. Two of the sites, Smith and B-Ave, are first order streams, UP-43 is second order, and the other three, I0-43, Nagel, and Kell-For, are third order sites. The third experiment was conducted on a third order portion of Augusta Creek (above the Kell-For site), Michigan in which ten gram pignut hickory and white oak packs were removed from November, 1973 through May, 1974.

\section{RESULTS AND DISCUSSION}

Results of the analysis using the simple, one independent variable, model for the three data sets are summarized in Table 2. The rate coefficients for these data are similar to those previously reported for the two leaf species examined (Petersen and Cummins, 1974). The hickory coefficients were higher, indicating faster processing when the two species were processed under identical conditions.

There was a significant $(p \varangle 0.05)$ lack of fit in three of the 13 data sets. Thus, the negative exponential model with days alone was not adequate in 23 percent of the cases examined. Only one of the 13 cases had a significant $(p 40.05)$ lack of fit using the model with days and degree days (Table 3). Therefore, the expanded model was adequate in 92 percent of the cases examined; all of the oak experiments and eight of the nine hickory cases were adequately fit. Testing the individual coefficients for their 
importance in the model reveals that both days and degree days are needed in three data sets, degree days alone is adequate once, days alone is sufficient once, and either can be used alone in eight cases. In four of 13 cases, degree days adds significantly $(p \& 0.05)$ to the model. In the other nine, days alone would be sufficient. Temperature significantly affected processing rates in four of the cases examined.

The Gull Lake oak experiments accounted for three of the nine cases where degree days were not needed in the model. The processing of oak leaves was too slow, and the length of the experiment too short to detect possible changes in the rate coefficient due to temperature, even though the temperature increased over $6^{\circ} \mathrm{C}$ at the upper two depths. In the hickory experiments conducted concurrently at the same sites in Gull Lake, processing was much faster. Changes in the hickory rates due to temperature were more easily observed and degree days was needed in the regressions for both depths.

Five of the other six cases in the group needing days only involved Augusta Creek sites. After an initial drop, the temperature remained essentially constant throughout the remainder of the October to April experiment. Since $\mathrm{T}$ was constant, $\mathrm{k}(\mathrm{T})$ was constant, and Equation (7) reduced to:

$$
\text { In } W_{D}=\ln w_{0}-k D(\text { see Equation }(2))
$$

Thus, over periods of relatively stable temperatures the addition of degree days does not significantly enhance the model. 
Improved fit is not the only advantage of the two variable model. The simpler, one variable model provides only a single rate coefficient for the "average" temperature of the experiment. This "average" rate constant may sometimes be misleading. Fitting the day-degree day model allows the calculation and examination of rate coefficients $(k(T))$ for all temperatures within the range of the experiment. The rate coefficient for a given temperature can be calculated by solving Equation(4) for $k(T)$ using any $T$ within the range of a given experiment. Rate coefficients for the low, high, and average mean daily temperatures of the 13 data sets are given in Table 4.

Rate coefficients for B-Ave and Nagel are similar in the single variable model, 0.0146 and 0.0141 , respectively, although one is a first order stream and the other a third (Table 2). It might be assumed that since the sites have near identical rates and are in the same drainage basin that processing dynamics and structure of the processing community would be similar. However, differences in the trend of the rate coefficients from the high to the low temperatures in the experiments indicates that processing dynamics may be very different at the two sites (Figure 1). The rate of processing at B-Ave, as well. as in the Smith site, decreased with an increase in temperature. Processing rates for Nagel, UP-43, 10-43, and Kell-For increase with temperature, as do those for the Gull Lake and Kellogg Forest data. The trends for first order streams, second and third order 
streams, and lake processing are each distinct (Figure 1). The first order streams may be characterized as shredder dominated systems, especially during the fall and winter months when processing rates increase as temperature decreases. Shredder life cycles are keyed to the large fall litter input. An example is the dominant shredder at Smith and B-Ave, a trichopteran Lepidostoma costalis. The larvae are in non-feeding stages from June through August. Litter shredding instars are present from late full through early spring, when there is a substantial coarse particular detritus (CPOM) reservoir. This fall-winter period of high shredder activity coincides with the period of low temperature in the stream. As the temperature begins to rise in the spring the Lepidostoma are in the terminal instars and beginning to pupate. Though microbial activity increases with temperature, invertebrate shredding diminishes, resulting in an overall processing rate decrease.

Rate coefficient trends obtained through the two variable model can provide clues for examining biological differences between aquatic systems or portions of systems. Microbial processing is more dominant in the second and third order portions of Augusta Creek, as well as the littoral zone of Gull Lake as indicated by processing rates which increase with temperature. Although shredders are present, they are apparently not as important to the processing community as in the headwater reaches of the stream. The decreasing microbial activity of the fall and 
winter is not offset by the increase in shredder activity, as it is in the Augusta Creek headwaters, therefore, processing rates do not increase substantially until the warming trends of spring induce higher microbial activity.

Temperature dependent processing rates also provide an explanation for the patterns of decay curves cited by Suberkropp et al. (1975). Hypothetical processing curves (Figure 2B, 2C) of pignut hickory at the third order Kell-For and the first order Smith sites of Augusta Creek were determined for three possible temperature regimes (Figure 2A) using the coefficients from the two variable model (Table 3). At Kell-For, a steadily increasing temperature trend would produce a linear relationship (Figure $2 \mathrm{~B}$ ), while a steady decrease in temperature would result in a curve similar to a single variable negative exponential. The processing curve for an experiment covering a period of temperature decrease, increase, and then a subsequent decrease is also shown. Since the first order Smith site had a negative temperature-rate relationship, while the third order Kell-F'or site processing rates increased with elevated temperature, distinctly different curves result (Figure 2C). Processing during a period of temperature increase at the Smith site would fit a negative exponential and over a period of decreasing temperature would appear linear. The curve resulting from the three phase temperature trend has a negative exponential appearance. The shape of a given processing curve and the rate at any point on that curve are dependent upon the experi- 
mental site and the temperature regimes over the experimental period. Processing curves which may be graphically linear, may actually represent a negative exponential type of decay.

\section{CONCLUSIONS}

The negative exponential model with two independent variable, days and degree days, adequately describes aquatic leaf litter processing for 92 percent of the data examined above. The use of a negative exponential model with both days and degree days offers several advantages over analysis of data with a single independent variable model (days only). The two variable model adequately fits processing curves which can't be described by the single variable model, due to nonconstant temperature trends during the experiments. The expanded model also allows calculation of rate coefficients for various temperatures of an experiment and provides a means of examining the effects of temperature on processing dynamics. Refinements of the two variable model may also provide insight into the interactions involved in litter processing. Since the more resistant veins are not processed at the same rate as the remainder of the leaf, partitioning leaf material into more than one component may improve model resolution. Although logarithmic transformation of the data produces a reasonable fit for litter processing, nonlinear regression estimates should be examined and compared. 
Other data sets have been fit using the transformed, two variable negative exponential model and it seems adequate in most cases. However, the model should be used with three cautions. First, failure of sample variances to remain homogeneous over the length of the curve may affect coefficient estimates. Second, the use of percent remaining, instead of actual data, in curve fitting may have an effect on the fit of the regression by distorting the variance of the observations. And third, the linear relationship of the rate coefficient to temperature may hold only over short temperature intervals.

If the negative exponential model is to be used in an analysis, the experiment should be designed with replication at sampling points 30 that a lack of fit test can be conducted. Results of the lack of fit test should be reported as an indication of the adequacy of the negative exponential model in a given experimental regime. The precision of the coefficients obtained by fitting the model should be indicated by giving the standard errors of each regression coefficient (Table 2, 3). Leaf litter processing is an integral part of headwater stream metabolism, and an understanding of factors affecting processing dynamics is vital to lotic ecosystem analysis. The transformed negative exponential model with days and degree days isolates the effect of temperature on processing, and can be a valuable tool in assessing the magnitudes of other factors. 
Acknowledgements: This paper wo,s supported by the Division of Biomedical and Bnvironmental. Research, U.S. Energy Research and Development Administration, Contract No. EY-76-S-02-2002 to KWC. Additional support was provided by the Departments of Statistics and Zoology, Brigham Young University to BJH, JRB and MWC. 
Andewartha, H. G., Birch, I. C: The distribution and abundance of animals. Chicago: University of Chicaほo Press (1954)

Barlocher, F., Kendrick, B.: Dynamics of the fungal population on leaves in a stream. J. Ecol. 62, 761-791 (1974)

Cummins, K. W.: Predicting variations in energy flow through a semi-controlled lotic ecosystem. Tech. Rep. Mich. State Univ. Inst. Water Res. 19, 1-21 (1972)

Cummins, K. W.: Structure and function of stream ecosystems. Bioscience 24, 631-641 (1974)

Cummins, K. W.: From headwater streams to rivers. Am. Bio. Teach. 39, 305-312 (1977)

Cummins, K. W•, Klug, M. J., Wetzel, R. G., Petersen, R. C., Suberkropp, K. F., Manny, B. A., Wuycheck, J. C., Howard, F. 0.: Organic enrichment with leaf leachate in experimental lotic ecosystems. Bioscience 22, 719-722 (1972)

Fisher, S. G., Likens, G. E.: Energy flow in Bear Brook, New Hampshire: An integrative approach to stream ecosystem metabolism. Ecol. Monogr. 43, 421-439 (1973)

Hall, C.A.S.: Migration and metabolism in a temperate stream ecosystem. Ecology 53, 585-604 (1972)

Neter, J., Wassermann, W.: Applied linear stratistical models. Homewood, Ill.: Richard D. Irwin, Inc. (1974) 
Olson, J. S.: Energy storage and the balance of producers and decomposers in ecological systems. Ecology 44, 322-330 (1963)

Park, D.: Accumulation of fungi by cellulose in a river. Trans. Br. Mycol. Soc. 63, 437-447 (1974)

Petersen, R. C., Cummins, K. W.: Leaf processing in a woodland stream. Freshwat. Biol. 4, 343-368 (1974)

Reice, S. R.: Finvironment patchiness and the breakdown of leaf litter in a woodland stream. Ecology 55, 1271-1282 (1974)

Sedell, J. R., Triska, F. J., Triska, N. S.: The processing of conifer and hardwood leaves in two coniferous forest streams: I. Weight loss and associated invertebrates. Verh. Int. Verein. Limnol. 19, 1617-1627 (1975)

Suberkropp, K., Klug, M. J., Cumnins, K. W.: Community processing of leaf litter in woodland streams. Verh. Int. Verein. Limnol. 19, 1653-1658 (1975)

Suberkropp, K॰, Klug, M.J.: Fungi and bacteria associated with leaves during processing in a woodland stream. Ecology 57, 707-719 (1976) 
Table 1. General Information for Gull Lake, Augusta Creek and Kellogg Forest (Augusta Creek) data sets.

\begin{tabular}{|c|c|c|c|c|c|c|c|c|c|c|c|c|}
\hline \multirow{2}{*}{ Data set } & \multirow{2}{*}{$\begin{array}{l}\text { Sampling } \\
\text { location }\end{array}$} & \multirow{2}{*}{ Leaf type } & \multirow{2}{*}{ Time period } & \multirow{2}{*}{$\begin{array}{r}\text { Total } \\
\text { days }\end{array}$} & \multirow{2}{*}{$\begin{array}{c}\text { Total } \\
\text { deg. } \\
\text { days }\end{array}$} & \multicolumn{4}{|c|}{ Water temperatures } & \multirow{2}{*}{$\begin{array}{l}\text { No. of } \\
\text { sampling } \\
\text { dates }\end{array}$} & \multirow{2}{*}{$\begin{array}{l}\text { Replicates } \\
\text { per sampling } \\
\text { date }\end{array}$} & \multirow{2}{*}{$\begin{array}{l}\text { Total } \\
\text { pack } \\
\text { removed }\end{array}$} \\
\hline & & & & & & Start & Low & End & Mean & & & \\
\hline \multirow[t]{2}{*}{ Gull Lake } & $2.5 \mathrm{M}$ & Oak & \multirow{2}{*}{$\begin{array}{l}\text { April 1975- } \\
\text { July } 1975\end{array}$} & 85 & 1610 & 12.3 & .12 .3 & $25.0 \star$ & 18.9 & 5 & 3 & 18 \\
\hline & $\begin{array}{rl}5.0 & M \\
12.0 \mathrm{M} \\
2.5 \mathrm{M} \\
6.0 \mathrm{M}\end{array}$ & $\begin{array}{l}\text { Oak } \\
\text { Oak } \\
\text { Hickory } \\
\text { Hickory }\end{array}$ & & $\begin{array}{l}85 \\
72 \\
85 \\
85\end{array}$ & $\begin{array}{r}1470 \\
638 \\
1610 \\
1470\end{array}$ & $\begin{array}{r}11.3 \\
7.1 \\
12.3 \\
11.3\end{array}$ & $\begin{array}{r}11.3 \\
7.1 \\
12.3 \\
11.3\end{array}$ & $\begin{array}{l}21.0^{\star} \\
11.2^{\star} \\
25.0^{\star} \\
21.0^{\star}\end{array}$ & $\begin{array}{r}17.3 \\
8.9 \\
18.9 \\
17.3\end{array}$ & $\begin{array}{l}4 \\
5 \\
6 \\
4\end{array}$ & $\begin{array}{c}3-6 \\
3 \\
3 \\
3-6\end{array}$ & $\begin{array}{l}15 \\
15 \\
18 \\
15\end{array}$ \\
\hline \multirow[t]{2}{*}{ Augusta Creek } & Smith & Hickory & \multirow[t]{2}{*}{$\begin{array}{l}\text { Oct. 1974- } \\
\text { Apri } 1975\end{array}$} & 172 & 704 & $11.8 *$ & 3.5 & 4.5 & 4.1 & 6 & $3-24$ & 43 \\
\hline & $\begin{array}{l}\text { B-Ave } \\
\text { UP-43 } \\
\text { LO-43 } \\
\text { ilagel } \\
\text { Kell-For }\end{array}$ & $\begin{array}{l}\text { Hickory } \\
\text { Hickory } \\
\text { Hickory } \\
\text { Hickory } \\
\text { Hickory }\end{array}$ & & $\begin{array}{l}172 \\
173 \\
187 \\
186 \\
186\end{array}$ & $\begin{array}{l}650 \\
665 \\
775 \\
771 \\
798\end{array}$ & $\begin{array}{l}10.2 \star \\
12.7 \star \\
13.2^{\star} \\
11.9 \star \\
11.2 *\end{array}$ & $\begin{array}{l}2.4 \\
2.1 \\
1.7 \\
2.0 \\
2.2\end{array}$ & $\begin{array}{l}4.3 \\
5.1 \\
7.1 \\
6.5 \\
6.7\end{array}$ & $\begin{array}{l}3.8 \\
3.8 \\
4.1 \\
4.1 \\
4.3\end{array}$ & $\begin{array}{l}6 \\
6 \\
6 \\
6 \\
6\end{array}$ & $\begin{array}{l}3-7 \\
3-5 \\
3-5 \\
3-5 \\
3-5\end{array}$ & $\begin{array}{l}26 \\
24 \\
23 \\
24 \\
23\end{array}$ \\
\hline \multirow{2}{*}{$\begin{array}{l}\text { Kellogg Forest } \\
\text { (Augusta Creek) }\end{array}$} & Kell-For & Oak & \multirow{2}{*}{$\begin{array}{l}\text { Nov. 1973- } \\
\text { May } 1974\end{array}$} & 179 & 818 & 6.8 & 1.4 & $13.4^{\star}$ & 4.6 & 17 & $7-10$ & 137 \\
\hline & Kell-For & Hickory & & 179 & 818 & 6.8 & 1.4 & $13.4^{\star}$ & 4.6 & 17 & $8-10$ & 138 \\
\hline
\end{tabular}

*High temperature

adepth for Gull Lake data, site for stream data 
Table 2. Average rate coefficients ( $k$ ) for all data sets using single independent variable (days) model. Whether or not days alone provides an adequate fit (ADEQ) is indicated. The standard error is given with each $k$.

\begin{tabular}{|c|c|c|c|c|c|c|}
\hline \multirow{2}{*}{ Data set } & \multirow{2}{*}{$\begin{array}{l}\text { Sampling } \\
\text { location }\end{array}$} & \multirow{2}{*}{$\begin{array}{c}\text { Stream } \\
\text { order }\end{array}$} & \multicolumn{2}{|c|}{ Hickory } & \multicolumn{2}{|l|}{ Oak } \\
\hline & & & k & ADEQ & k & ADEQ \\
\hline Gull Lake & $\begin{array}{r}2.5 \mathrm{M} \\
6.0 \mathrm{M} \\
12.0 \mathrm{M}\end{array}$ & $\begin{array}{l}\text { NA } \\
\text { NA } \\
\text { NA }\end{array}$ & $.0508 \pm .0120$ & $\begin{array}{l}\text { No } \\
\text { No } \\
--\end{array}$ & $\begin{array}{l}.0079 \pm .0007 \\
.0037 \pm .0005 \\
.0015 \pm .0004\end{array}$ & $\begin{array}{l}\text { Yes } \\
\text { Yes } \\
\text { Yes }\end{array}$ \\
\hline Augusta Creek & $\begin{array}{l}\text { Smith } \\
\text { B-Ave } \\
\text { Upper-43 } \\
\text { Lower-43 } \\
\text { Nagel } \\
\text { Kell-For }\end{array}$ & $\begin{array}{l}7 \\
1 \\
3 \\
3 \\
3 \\
3\end{array}$ & $\begin{array}{l}.0273 \pm .0019 \\
.0146 \mp .0017 \\
.0079 \mp .0011 \\
.0072 \mp .0007 \\
.0142 \pm .0016 \\
.0071 \pm .0007\end{array}$ & $\begin{array}{l}\text { Yes } \\
\text { Yes } \\
\text { Yes } \\
\text { Yes } \\
\text { Yes } \\
\text { Yes }\end{array}$ & $\begin{array}{l}--- \\
--- \\
--- \\
--- \\
--- \\
---\end{array}$ & $\begin{array}{l}--- \\
--- \\
--- \\
--- \\
---\end{array}$ \\
\hline $\begin{array}{l}\text { Kellogg Forest } \\
\text { (Augusta Creek) }\end{array}$ & Kell-For & 3 & $.0249 \pm .0021$ & Yes & $.0047 \pm .0002$ & No \\
\hline
\end{tabular}

---indicates no data obtained 
Table 3. Coefficients for day $\left(b_{0}\right)$ and degree days $\left(b_{2}\right)$ for all data sets. The standard error is given with each coefficient. Results of the test to determine if the individual factor is needed in the model and the test for adequacy (ADEQ) of the two variable model (lack of fit test) are also indicated.

\begin{tabular}{|c|c|c|c|c|c|c|c|c|c|c|c|c|}
\hline \multirow{2}{*}{ Data set } & \multirow{2}{*}{$\begin{array}{l}\text { Sampling } \\
\text { location }\end{array}$} & \multirow{2}{*}{$\begin{array}{c}\text { Stream } \\
\text { order }\end{array}$} & \multicolumn{5}{|c|}{ Hickory } & \multicolumn{5}{|c|}{ Oak } \\
\hline & & & $b_{0}$ (days) & Heeded & $b_{1}($ days $)$ & Needed & ADEQ & $b_{0}$ (days) & Needed & $b_{1}\left({ }^{0}\right.$ days $)$ & Needed & ADEQ \\
\hline Gull Lake & $\begin{array}{r}2.5 \mathrm{M} \\
6.0 \mathrm{M} \\
12.0 \mathrm{M}\end{array}$ & $\begin{array}{l}N A \\
\text { HA } \\
\text { HA }\end{array}$ & $\begin{array}{l}-.1124 \pm .0700 \\
-.0042 \pm .0072\end{array}$ & $\begin{array}{l}\text { Yes } \\
\text { No } \\
\cdots\end{array}$ & $.0085 \pm .0036$ & $\begin{array}{l}\text { Yes } \\
\text { No } \\
\cdots\end{array}$ & $\begin{array}{l}\text { No } \\
\text { Yes } \\
\cdots--\end{array}$ & $\begin{array}{r}.0019 \pm .0047 \\
-.0018 \mp .0027 \\
-.0016 \pm .0039\end{array}$ & $\begin{array}{l}\text { No } \\
\text { No } \\
\text { No }\end{array}$ & $\begin{array}{l}.0003 \pm .0002 \\
.0003 \mp .0002 \\
.0004 \pm .0004\end{array}$ & $\begin{array}{l}\text { No } \\
\text { No } \\
\text { No }\end{array}$ & $\begin{array}{l}\text { Yes } \\
\text { Yes } \\
\text { Yes }\end{array}$ \\
\hline Augusta Creek & $\begin{array}{l}\text { Smith } \\
\text { B-Ave } \\
\text { UP-43 } \\
\text { LO-43 } \\
\text { Nagel } \\
\text { Kell-For }\end{array}$ & $\begin{array}{l}1 \\
1 \\
3 \\
3 \\
3 \\
3\end{array}$ & $\begin{array}{l}.0366 \pm .0162 \\
.0176 \mp .0123 \\
.0052 \mp .0057 \\
.0021 \mp .0023 \\
.0093 \mp .0080 \\
.0031 \pm .0033\end{array}$ & $\begin{array}{l}\text { Yes } \\
\text { Ho } \\
\text { No } \\
\text { No } \\
\text { No } \\
\text { No }\end{array}$ & $\begin{array}{r}-.0025 \mp .0044 \\
-.0009 \mp .0036 \\
-.0008 \mp .0017 \\
.0015 \mp .0006 \\
.0013 \mp .0022 \\
.0011 \mp .0009\end{array}$ & $\begin{array}{l}\text { No } \\
\text { No } \\
\text { No } \\
\text { Yes } \\
\text { No } \\
\text { Ho }\end{array}$ & $\begin{array}{l}\text { Yes } \\
\text { Yes } \\
\text { Yes } \\
\text { Yes } \\
\text { Yes } \\
\text { Yes }\end{array}$ & $\begin{array}{l}\cdots \\
\cdots \\
\cdots \\
\cdots \\
\cdots\end{array}$ & $\begin{array}{l}=- \\
=- \\
=- \\
=- \\
=\end{array}$ & $\begin{array}{l}-.- \\
\cdots- \\
\cdots- \\
\cdots-\end{array}$ & $\begin{array}{l}- \\
-- \\
=- \\
-- \\
-\end{array}$ & $\begin{array}{l}\cdots- \\
\cdots \\
\cdots- \\
-- \\
--\end{array}$ \\
\hline $\begin{array}{l}\text { Kellogg Forest } \\
\text { (Augusta Creek) }\end{array}$ & Kell-For & 3 & $.0019 \pm .0047$ & Yes & $.0040 \pm .0013$ & Yes & Yes & $.0022 \pm .0004$ & Yes & $.0008 \pm .0001$ & Yes & Yes \\
\hline
\end{tabular}


Table 4. Rate coefficients $k(T)$ calculated for the low, mean and high water temperatures of each data set.

\begin{tabular}{|c|c|c|c|c|c|c|c|c|c|c|c|c|c|c|}
\hline Data set & $\begin{array}{l}\text { Sampling } \\
\text { location }\end{array}$ & $\begin{array}{c}\text { Stream } \\
\text { order }\end{array}$ & \multicolumn{6}{|c|}{ Hickory } & \multicolumn{6}{|c|}{ Oak } \\
\hline Augusta Creek & $\begin{array}{l}\text { Smith } \\
\text { B-Ave } \\
\text { Upper-43 } \\
\text { Lower-43 } \\
\text { Nagel } \\
\text { Kell-For }\end{array}$ & $\begin{array}{l}1 \\
1 \\
3 \\
3 \\
3 \\
3\end{array}$ & $\begin{array}{l}3.5 \\
2.4 \\
2.1 \\
1.7 \\
2.0 \\
2.2\end{array}$ & $\begin{array}{l}.0279 \\
.0155 \\
.0069 \\
.0046 \\
.0120 \\
.0055\end{array}$ & $\begin{array}{l}4.1 \\
3.8 \\
3.8 \\
4.1 \\
4.1 \\
4.3\end{array}$ & $\begin{array}{l}.0264 \\
.0143 \\
.0082 \\
.0082 \\
.0148 \\
.0077\end{array}$ & $\begin{array}{l}11.8 \\
10.2 \\
12.7 \\
13.2 \\
11.9 \\
11.2\end{array}$ & $\begin{array}{l}.0071 \\
.0088 \\
.0155 \\
.0217 \\
.0253 \\
.0152\end{array}$ & $\begin{array}{l}-.- \\
--. \\
--. \\
--. \\
--.\end{array}$ & $\begin{array}{l}--- \\
-\ldots \\
-\cdots \\
--. \\
--\end{array}$ & $\begin{array}{l}--- \\
-- \\
--- \\
--- \\
--\end{array}$ & $\begin{array}{l}--- \\
--- \\
--- \\
--- \\
--\end{array}$ & $\begin{array}{l}--- \\
--- \\
--- \\
--- \\
--\end{array}$ & $\begin{array}{c}--- \\
\cdots- \\
\cdots- \\
\cdots \\
\cdots\end{array}$ \\
\hline $\begin{array}{l}\text { Kellogg Forest } \\
\text { (Augusta Creek) }\end{array}$ & Kell-For & 3 & 1.4 & .0175 & 4.6 & .0303 & 13.4 & .0655 & 1.4 & .0033 & 4.6 & .0057 & 13.4 & .0125 \\
\hline
\end{tabular}

"The negative sign associated with this coefficient would indicate that the model predicts that leaf packs would gain weight at the temperature associated with it. This result is due to the lack of fit of the model for that data set. 
F'igure Legends

Figure 1. Plots of $k(T)$ values for hickory. A plot for the 2.5

M Gull Lake data was not included because of the model's significant lack of fit for this set.

Figure 2. A.) Hypothetical temperature regimes for simulating processing curves. B.) Processing curves for Kell-For using $b_{0}$ and $b_{1}$ values from Table 3 and above hypothetical temperature regimes. C.) Processing curves for Smith using $b_{0}$ and $b_{1}$ values from Table 3 and above hypothetical temperature regimes. 

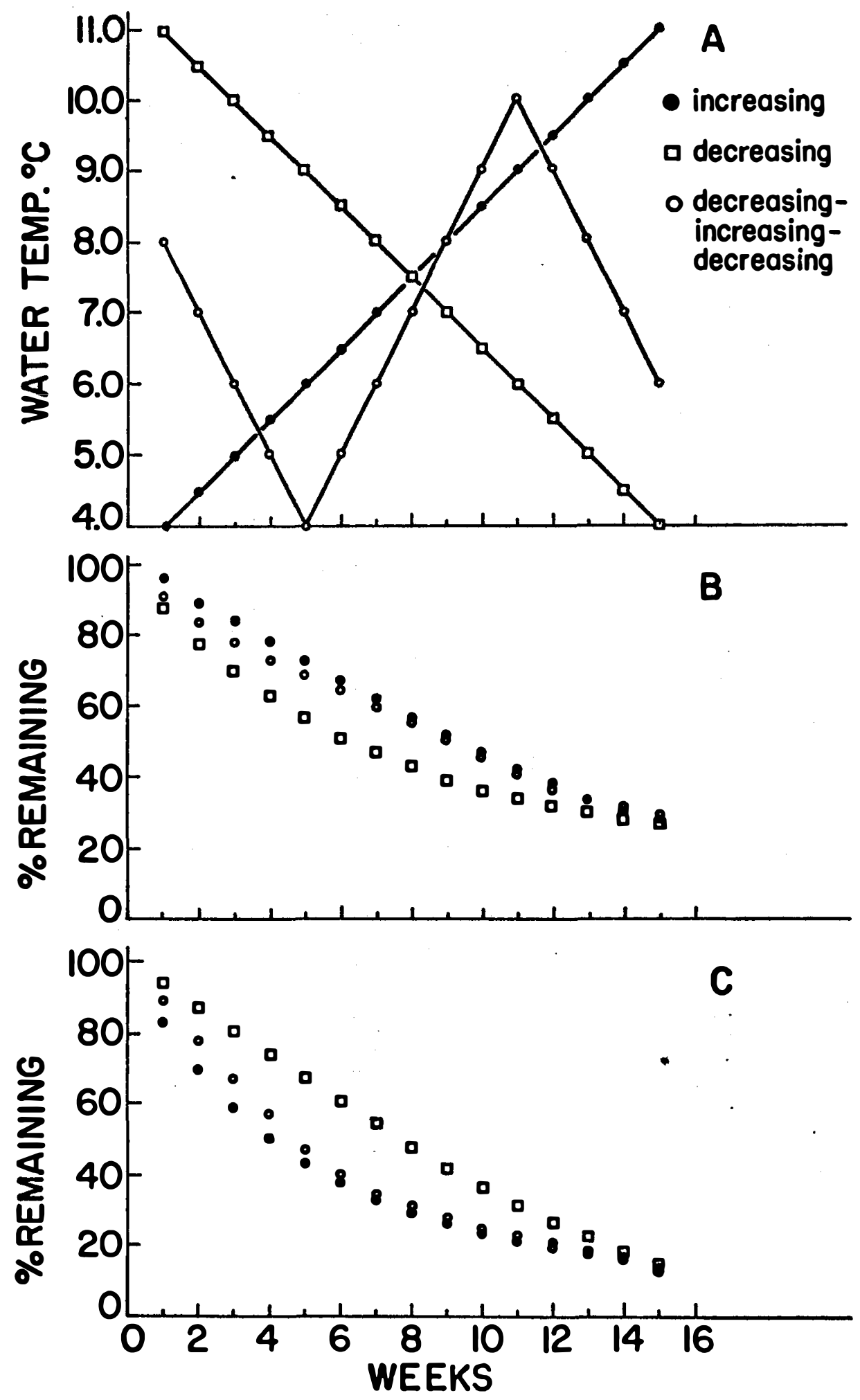


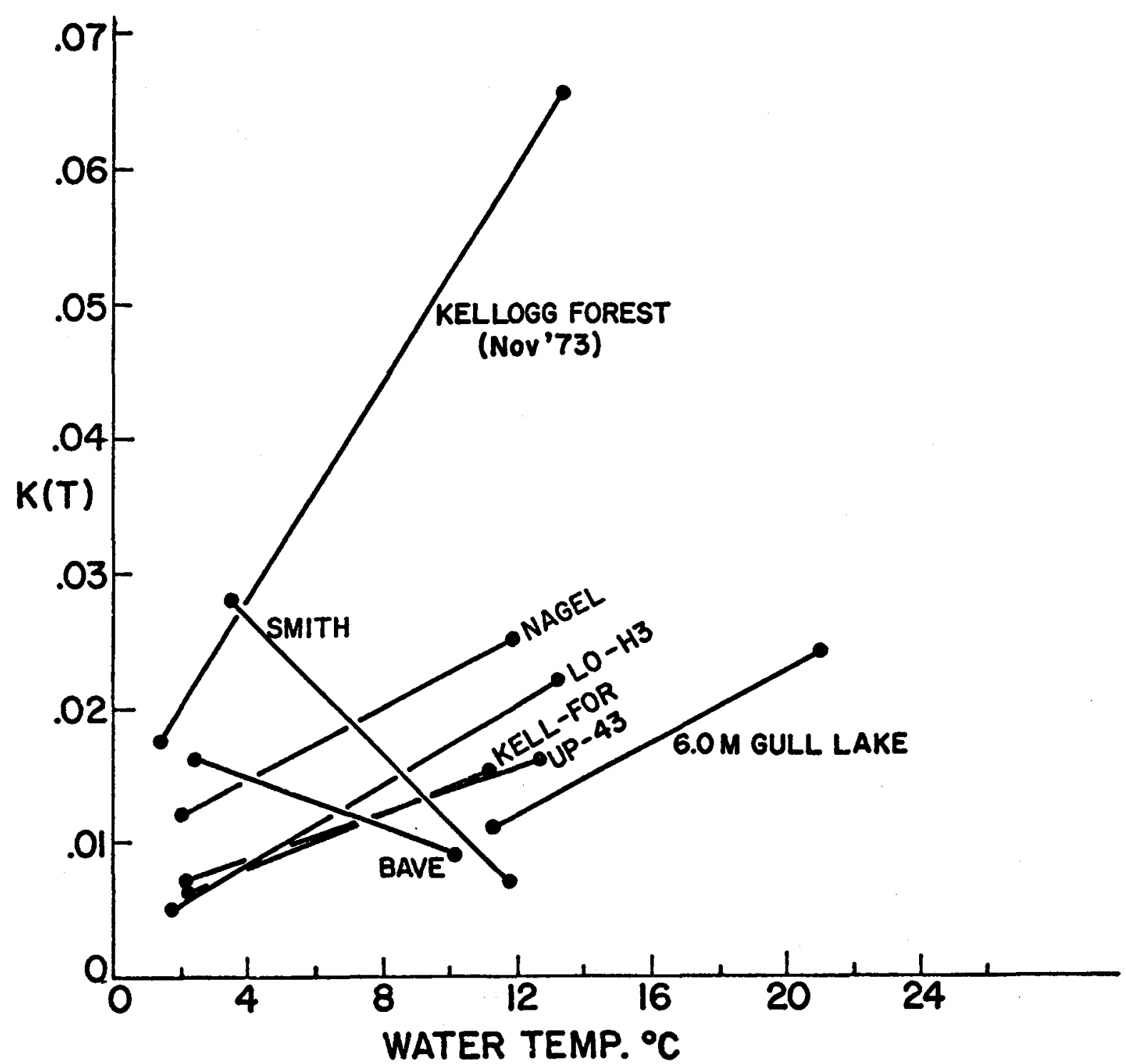




\title{
LEAF LITTER PROCESSING IN AQUATIC SYSTENIS:
}

A TWO VARIABLE MODEL

Boyd Jay Hanson

Department of Zoology

M. S. Degree, December 1977

\begin{abstract}
The adequacy of the negative exponential model with one independent variable, days or accumulated time, as a descriptive equation for aquatic leaf litter processing was examined. The effect of adding a second independent variable, degree days or accumulated temperature, to the model was also examined. The two variable negative exponential model was shown to have at least two advantages over the single variable model. The two variable model adequately fits litter processing data for more cases than the single variable model. The expanded model also allows determination of rate coefficients for various temperature levels of the experiment rather than assuming a single, constant rate coefficient as the simpler model does. The trends of the temperature dependent rate coefficient can be used to examine processing differences between experiments for different sites and seasons.
\end{abstract}

COMMITTEE APPROVAL: 